\title{
Synthesis, Characterization, and Evaluation of Antitumor Potential in MCF-7 Cells of Ruthenium-Derived Compounds
}

\author{
Moraes Fabricio Tarso ${ }^{1}$, Galvão Anderson Dourado ${ }^{1}$, Fortaleza Dário Batista1, \\ Amorin Kelly Aparecida da Encarnação ${ }^{1}$, Sousa Claudia Cristina ${ }^{2}$, \\ Honorio-França Adenilda Cristina², França Eduardo Luzia², Costa Daniel Tizo3, \\ Santos Wagner Batista ${ }^{*}$ \\ ${ }^{1}$ Institute of Exact Sciences and Earth, Federal University of Mato Grosso, Barra do Garças/MT, Brazil \\ ${ }^{2}$ Institute of Biological and Health Sciences, Federal University of Mato Grosso, Barra do Garças/MT, Brazil \\ ${ }^{3}$ UniRv-University of Rio Verde, Rio Verde/Go, Brazil \\ Email: ^fabriciotarso@hotmail.com, ^wbsantos@ufmt.br
}

How to cite this paper: Tarso, M.F., Dourado, G.A., Batista, F.D., da Encarnação, A.K.A., Cristina, S.C., Cristina, H.-F.A., Luzia, F.E., Tizo, C.D. and Batista, S.W. (2020) Synthesis, Characterization, and Evaluation of Antitumor Potential in MCF-7 Cells of Ruthenium-Derived Compounds. Advances in Biological Chemistry, 10, 86-98. https://doi.org/10.4236/abc.2020.103007

Received: May 5, 2019

Accepted: June 25, 2020

Published: June 28, 2020

Copyright $\odot 2020$ by author(s) and Scientific Research Publishing Inc. This work is licensed under the Creative Commons Attribution International License (CC BY 4.0).

http://creativecommons.org/licenses/by/4.0/

\begin{abstract}
To synthesize, characterize and evaluate the antitumor potential derived from ruthenium compounds was generated in this study, from the precursor $\mathrm{K}\left[\mathrm{RuCl}_{4}(\right.$ bipy) $]$ a route in a simple and reproducible synthesis for a novel compound of coordinating $\mathrm{Ru}^{+3}$ with bipy and L-trip. The spectroscopic characterization in the middle infrared region (FTIR) shows the interactions between $\mathrm{Ru}$-(L-trip), evidenced by the displacement of the carboxylate ion band for higher energies, and also by the displacements of aliphatic amine bands, suggesting that bidentate coordination of the L-trip ligand occurred. Analysis of the results obtained with thermoanalytical techniques showed that the minimum formula of the compound, $\left[\mathrm{RuCl}_{2}\right.$ (bipy)(L-trip) $] 1 / 2 \mathrm{H}_{2} \mathrm{O}$. Evaluation of the antitumor potential of precursor $\mathrm{K}\left[\mathrm{RuCl}_{4}(\right.$ bipy) $]$ showed the toxic effects on MCF-7 cell line, but did not show selectivity and not reached PBMC cells to the same extent. The evaluation of the antitumor potential of the newly synthesized compound, $\left[\mathrm{RuCl}_{2}\right.$ (bipy)(L-trip)], demonstrated that the insertion of an L-tryptophan molecule into the precursor coordination sphere made it selective when compared to PBMC cells, for MCF-7 type tumor cells.
\end{abstract}

\section{Keywords}

Ruthenium Compounds, Pyridine Ligands, Antitumor Activity, Tryptophan Amino Acid, MCF-7 Cells, Ligand N-Heterocyclic 


\section{Introduction}

From the studies conducted by Rosenberg and colleagues [1] [2] [3], platinum-based coordination compounds are among the most used drugs in the treatment of cancer. Since studies by Rosenberg and colleagues platinum-derived coordination compounds have been among the most widely used drugs in cancer treatment [4]. However, these compounds exhibit high toxicity, leading patients to present some side effects such as high nephrotoxicity, nausea, vomiting, anorexia, ototoxicity, neurotoxicity and develop resistance to drugs [4] [5] [6].

The toxic effects caused by platinum-derived compounds have prompted several researchers to develop new drugs. Research involving ruthenium-derived compounds as drugs in the treatment of malignant neoplasms has shown promise [7] [8]. This class of compounds presents characteristics such as considerable cytotoxicity, antimetathesis properties and low toxicity when compared to platinum derived compounds.

Like iron, ruthenium is known to have the ability to bind transferrin protein. Due to the high demand for iron, cancer cells tend to increase the numbers of transferrin receptors on their surfaces, capturing them in greater numbers. It is believed that by mimicking iron, a higher concentration of ruthenium is directed to cancer cells, which would explain the lower toxicity of this class of compounds [7] [8].

Considerable cytotoxicity may be related to interactions between the metallic center and the nitrogenous bases of DNA. The results obtained by Gallori [9], suggest that compounds are known as NAMI (sodium trans-(dimethylsulfoxide) (imidazole) tetrachloro ruthenate(III)) and RAP (dichloro-1,2-propylene diamine tetraacetate ruthenium(III)) are capable, in vitro, of interacting with DNA causing changes in its conformation, inhibiting its recognition and cutting by restriction enzymes. However, these compounds only cause considerable DNA damage at relatively high concentrations when compared to cisplatin. Some compounds derived from $\mathrm{Ru}^{+3}$ and $\mathrm{Ru}^{+2}$ with an amine, [10] N-heterocyclic [11] [12], and alkyl sulfoxide linkers [13] also demonstrated potential activity antimetastatic. Among the compounds with this property stands out NAMI-A [14], this compound has several peculiarities such as excellent selective activity against lung metastases from various solid tumors [14] [15] [16] and very low in vitro cytotoxicity in a panel of 60 strains solid tumor cells [17].

Two other ruthenium-derived compounds have been intensively studied, cis-(dichloro)tetraamimruthenium(III) chloride and a synthesis intermediate, cis-tetraamim(oxalate)ruthenium(III) dithionate [18]-[24].

Studies in mice transplanted with S- 180 cells and treated with cis- $\left[\mathrm{RuCl}_{2}\left(\mathrm{NH}_{3}\right)_{4}\right]$ $\mathrm{Cl}$ have shown that the compound is well tolerated at therapeutic doses, presenting very low toxicity to the host and extending its life span [20]. Further studies have shown that the compound is selective, exerting significant toxic activity in A-20, SK-Br-3 and S-180 strains, moderate in Jurkat cells and very low toxicity in PBMC cells when compared to A-20, SK-Br-3 and S-180 [23].

All of these properties cited above, prompted us to make a new ruthe- 
nium-derived compound and test its antitumor potential. Thus, in this work the synthesis and characterization of a new ruthenium compound are reported, the new compound was biologically tested for a preliminary evaluation of its antitumor potential.

\section{Experimental Section}

\subsection{Synthesis}

Synthesis of $K\left[\mathrm{RuCl}_{4}(\right.$ bipy $\left.)\right]$ : The entire synthesis procedure was performed as described by James [25], with some changes.

In a flat-bottomed flask, $0.5014 \mathrm{~g} \mathrm{RuCl}_{3} \cdot \mathrm{nH}_{2} \mathrm{O}$ was solubilized in $25.0 \mathrm{~mL}$ of methanol, the resulting solution was stirred at $200 \mathrm{rpm}$ for 30 minutes for further addition of $0.3047 \mathrm{~g}$ solubilized bipy in $25.0 \mathrm{~mL}$ of methanol. After the addition of bipy, the system was stirred and heated to $100^{\circ} \mathrm{C}$ under reflux. After 2 hours, $400.0 \mathrm{~mL}$ of methanol and $0.3059 \mathrm{~g}$ of $\mathrm{KCl}$ were added thus ensuring the excess counter ion $\mathrm{K}^{+}$. The system was kept under the same stirring conditions and temperature for a further 20 hours. After 20 hours the red solution had its temperature reduced to $60^{\circ} \mathrm{C}$ and was maintained until the volume was reduced to $15 \mathrm{~mL}$. The brown precipitate was separated by vacuum filtration and desiccated for 24 hours. Yield: $94.24 \%$.

Purification: In a $1000.0 \mathrm{~mL}$ beaker, $0.7918 \mathrm{~g}$ of $\mathrm{K}\left[\mathrm{RuCl}_{4}(\right.$ bipy $\left.)\right]$ and a $\mathrm{KCl}$ spatula tip in $1000.0 \mathrm{~mL}$ of a $36.5 \%-38 \% \mathrm{HCl} / 1$ : 1 water solution were solubilized. The system then remained under stirring and bathing at $100^{\circ} \mathrm{C}$ for 30 minutes. After 30 minutes, the system was hot filtered by gravity and the orange-colored supernatant was placed in a $100^{\circ} \mathrm{C}$ bath to reduce its volume to $\sim 30.0 \mathrm{~mL}$. Slow cooling of the solution generated red, needle-shaped crystals. Yield: $94 \%$.

Synthesis of $\left[\mathrm{RuCl}_{2}\right.$ (bipy)(L-trip)]: In a $25.0 \mathrm{~mL}$ beaker, $0.0478 \mathrm{~g}$ L-trip, 0.0195 $\mathrm{g} \mathrm{NaHCO}_{3}$ and $\sim 5.0 \mathrm{~mL}$ distilled water were added. The system was stirred for 30 minutes for further addition of $0.1012 \mathrm{~g}$ of $\mathrm{K}\left[\mathrm{RuCl}_{4}(\mathrm{bipy})\right]$. After 1 hour, the system was vacuum filtered. The precipitate was dried with ether and desiccated with silica for 24 hours. At the end of this procedure, $0.0680 \mathrm{~g}$ was obtained. Yield: $55.42 \%$.

The same procedure was repeated twice, and in one of them the system was heated to $60^{\circ} \mathrm{C}$ and in the other, the synthesis time was extended by another 3 hours.

\subsection{Cytotoxic Evaluation of Ruthenium Compounds.}

Preparation of Ruthenium Compound Solutions: For the cytotoxic evaluation of ruthenium compounds a $66.0 \mu \mathrm{M}$ aqueous solution containing the complex.

Preparation of cell lines used

Tumor Cells. To evaluate the cytotoxicity of ruthenium compounds, we used breast adenocarcinoma-type (MCF-7) ATCC (American Type Culture Collection, USA) cell lines. The strain was grown and frozen in liquid nitrogen for sto- 
rage and subsequent use. To perform the biological assays, tumor cells were cultured in RPMI medium, plus HEPES, penicillin, streptomycin, sodium bicarbonate, sodium pyruvate, and fetal bovine serum. Cells were cultured in cell culture flasks and kept in an oven at $37^{\circ} \mathrm{C}$ at $5 \% \mathrm{CO}_{2}$ until cell monolayer formation. Subsequently, the culture flasks were washed with $5 \mathrm{~mL}$ RPMI and subjected to $1.0 \mathrm{~mL}$ trypsin-EDTA, until the cells detach from the bottom of it. For trypsin neutralization, cells were homogenized with an undefined volume of culture medium plus $10 \%$ fetal serum. The suspension containing MCF-7 cells was then adjusted to $2.0 \times 10^{4}$ cells $/ \mathrm{mL}$.

Healthy Cell Lines: As healthy cells, the PBMC strain was used. To obtain these cells, blood samples were collected in tubes containing the EDTA anticoagulant. Cell populations were separated by a ficoll-paque density gradient. In a falcon tube, $3.0 \mathrm{~mL}$ of ficoll-paque was added followed by the slow addition of $\sim 5.0 \mathrm{~mL}$ of blood, thus forming two phases. The system was centrifuged at 1500 rpm for 40 minutes at room temperature. After this time, the mononuclear cell ring was removed and transferred to a new tube. To the tube containing the mononuclear cell, the ring was added $3 \mathrm{~mL}$ of PBS and stirred for homogenization of the system. After stirring the system was centrifuged for 10 minutes at $15,000 \mathrm{rpm}$ at room temperature, the supernatant was then discarded and this step repeated, then $1 \mathrm{~mL}$ PBS was added. Cells were counted in a Neubauer camera and cell suspension adjusted to $2.0 \times 10^{6}$ cells $/ \mathrm{mL}$.

Cell incubation: For the test, the cells were seeded in Falcon tubes, with or without ruthenium-derived compounds. The cells were incubated for $24 \mathrm{~h}$ in an oven at $37^{\circ} \mathrm{C}$ and atmosphere containing $5 \% \mathrm{CO}_{2}$ (Table 1).

Cell viability assay by acridine orange staining method: At the end of the incubation period, the falcon tubes were centrifuged at $1500 \mathrm{rpm}$ for 10 minutes and had their supernatant discarded. The pellet formed was stained with $200.0 \mu \mathrm{l}$ of freshly prepared acridine orange solution (concentration $14.4 \mathrm{mg} / \mathrm{mL}$ ) and allowed to stand for 1 minute for dye action. The resulting solution was resuspended in medium 199, after which the tubes were centrifuged and washed with PBS a further 2 times. Stained cells were placed on microscope slides $(26 \times 76$ $\mathrm{mm})$ and, after mounting with coverslips $(24 \times 24 \mathrm{~mm})$, were analyzed by blind fluorescence microscopy (Nikkon Eclipse E200). The cell viability index was obtained by counting. For each treatment at least 100 cells were analyzed. Green

Table 1. Volume used in $\mu$ l.

\begin{tabular}{cc}
\hline Group & Vol. $(\mu \mathrm{l})$ \\
\hline PBMC & 500.0 \\
PBMC+Compound $K\left[\right.$ RuCl $_{4}($ bipy $\left.)\right]$ & $500.0+50.0$ \\
$M C F-7$ & 500.0 \\
$M C F-7+$ Compound $\left[R u C l_{2}(\right.$ bipy $)(L$-trip $\left.)\right]$ & $500.0+50.0$ \\
$M C F-7+$ Compound $K\left[\right.$ RuCl $_{4}($ bipy $\left.)\right]$ & $500.0+50.0$ \\
\hline
\end{tabular}


cells were considered alive and orange cells considered dead.

Statistical analysis: For the proper statistical treatment, the analysis of variance test (ANOVA) was performed, followed by the multiple comparisons test, Tukey test. Differences between treatments were considered significant when the $\mathrm{p}$-value was less than $0.05(\mathrm{p}<0.05)$.

\subsection{Characterization Methods}

The synthesized compounds were characterized by UV-VIS and FTIRmed spectroscopy, and TG-DTA thermal analysis.

The measurements in the FTIRmed region were obtained in a Perkin Elmer Fourier transform spectrophotometer, model Perkin Elmer Spectrometer 100. Resolution of $4 \mathrm{~cm}^{-1}$, in the region between $4000-600 \mathrm{~cm}^{-1}$, using an accessory for the technique of ATR with germanium crystal.

The measurements in the UV-VIS regions were obtained using a Varian spectrophotometer, model Cary 50 Scan. To perform these analyzes, a quartz cell was used, with an optical path of $1 \mathrm{~cm}$, and a scanning range at wavelengths of 200 $800 \mathrm{~nm}$.

TG-DTA thermal analyzes of the synthesized compound were performed in a TA Instruments thermoanalyst, model SDT 2960, consisting of a horizontal mass comparator with a maximum capacity of $20.00 \mathrm{mg}$ and a sensitivity of $1 \mu \mathrm{g}$. The analyzes were performed in the temperature range of $30^{\circ} \mathrm{C}$ to $1000^{\circ} \mathrm{C}$, with a heating rate of $10^{\circ} \mathrm{C} \cdot \mathrm{min}^{-1}$ and a dry air atmosphere with a flow rate of 100 $\mathrm{mL} \cdot \mathrm{min}^{-1}$. The sample mass used was of the order of $7.00 \mathrm{mg}$ in $\alpha$-alumina crucible.

\section{Results and Discussion}

Thermal Analysis TG-DTA Curves. The TG-DTA curves shown in Figure 1 show the thermal decomposition of the compound $\left[\mathrm{RuCl}_{2}\right.$ (bipy)(L-trip)] $1 / 2 \mathrm{H}_{2} \mathrm{O}$ to $900^{\circ} \mathrm{C}$ and formation of the $\mathrm{RuO}_{2}$ residue with an error of $2.57 \%$ ( $\mathrm{TG}=$ 27.20\%; Calcd $=24.63 \%$ ).

Table 2 shows the thermal decomposition of the compound $\left[\mathrm{RuCl}_{2}\right.$ (bipy) (L-trip)] $1 / 2 \mathrm{H}_{2} \mathrm{O}$ in five stages accompanied by a single exothermic event.

A small mass loss is observed up to $115^{\circ} \mathrm{C}$, which is attributed to hydration water, since qualitative tests with silver nitrate showed the absence of chloride ions, thus indicating that chlorine atoms are directly attached to the metal center. The presence of chlorine in the coordination sphere indicates that all available sites for links are already occupied, making it impossible to interact with the water and the metallic center. From $115^{\circ} \mathrm{C}$, it is possible to observe a marked loss of mass accompanied by an exothermic peak, indicating the oxidative decomposition of the ligands. In addition to what has already been discussed, there is a small mass gain in the region between $500^{\circ} \mathrm{C}$ and $700^{\circ} \mathrm{C}$. This small mass gain is attributed to the oxidation of the metal from $\mathrm{Ru}^{+3}$ to $\mathrm{Ru}^{+4}$, thus justifying the formation of the proposed residue. Studies conducted Guo-Nan [26], involving 


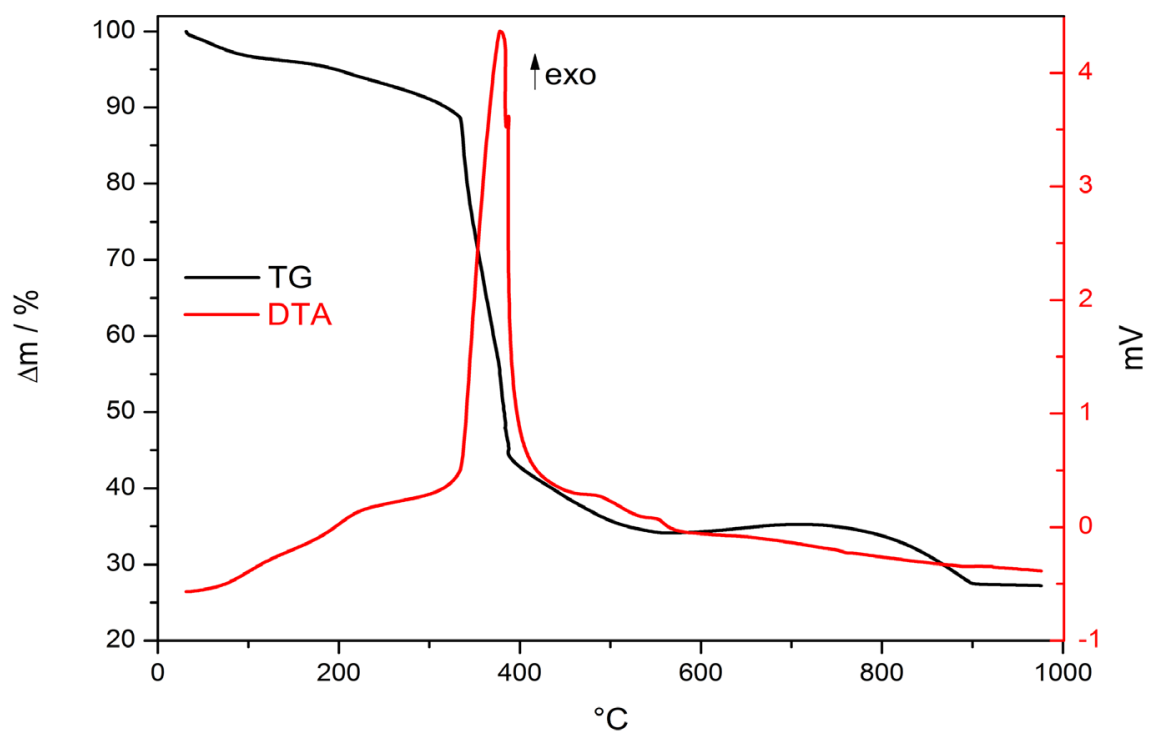

Figure 1. TG-DTA curves of the compound $\left[\mathrm{RuCl}_{2}\right.$ (bipy)(L-trip)] $1 / 2 \mathrm{H}_{2} \mathrm{O}$.

Table 2. Thermal decomposition steps for $\left[\mathrm{RuCl}_{2}\right.$ (bipy)(L-trip) $] \cdot 1 / 2 \mathrm{H}_{2} \mathrm{O}$.

\begin{tabular}{cccccc}
\hline \multicolumn{5}{c}{ Process Steps } \\
\hline$T^{\circ} \mathrm{C}$ & $35-115$ & $115-315$ & $315-395$ & $395-548$ & $548-900$ \\
$\Delta m \%$ & 3.53 & 6.23 & 46.96 & 9.01 & 7.07 \\
Event & - & - & $378^{\circ} \mathrm{C} /$ exo & - & - \\
\hline
\end{tabular}

the compound [ $\mathrm{Ru}$ (bipy) $)_{2}(\mathrm{~L}$-trip) $] \mathrm{ClO}_{4} \cdot 3 \mathrm{H}_{2} \mathrm{O}$, demonstrated higher thermal stability. As reported by the authors, such a compound demonstrated stability up to $220^{\circ} \mathrm{C}$ with water output up to $230^{\circ} \mathrm{C}$, followed by marked loss of mass up to $238^{\circ} \mathrm{C}$, attributed to the L-trip ligand output. This higher thermal stability may be related to the number of bipy coordinates to the metal, which provides a greater number of intermolecular interactions. No mention is made of the mass loss steps involving bipy ligands and $\mathrm{ClO}_{4}^{-1}$ ion as well as the residue formed. Thermal characterization and qualitative tests with the observation of water outflow in the test tube, absence of precipitate in $\mathrm{AgNO}_{3}$ tests, and the possible formation of $\mathrm{RuO}_{2}$ residue, suggest stoichiometry $\left[\mathrm{RuCl}_{2}\right.$ (bipy)(L-trip)] $\cdot 1 / 2 \mathrm{H}_{2} \mathrm{O}$.

$F_{T I R_{\text {med }}}$ Spectroscopy. Figure 2 illustrates the $\mathrm{FTIR}_{\text {med }}$ spectra of the compounds studied. A significant difference can be observed between the spectrum of $\left[\mathrm{RuCl}_{2}\right.$ (bipy)(L-trip)], its precursor $\mathrm{K}\left[\mathrm{RuCl}_{4}(\right.$ bipy) $]$, and the free L-trip ligand. The most relevant changes occur in the carboxylate ion and aliphatic amine regions.

The presence of characteristic bands such as ${ }_{v}\left(\mathrm{NH}_{3}^{+}\right)$and ${ }_{\delta}\left(\mathrm{NH}_{3}^{+}\right)$, as well as the position of the carboxylate ion stretching vibrations in the free L-trip ligand, may indicate whether it is in zwitterion form [27] [28]. In the spectrum in the above spectrum these bands are observed at $3078 \mathrm{~cm}^{-1}$ for $v_{\text {as }}\left(\mathrm{NH}_{3}{ }^{+}\right), 2073 \mathrm{~cm}^{-1}$ for torsional oscillations of the group $\left(\mathrm{NH}_{3}{ }^{+}\right), 1659 \mathrm{~cm}^{-1}$ for $\delta\left(\mathrm{NH}_{3}{ }^{+}\right), 1582 \mathrm{~cm}^{-1}$ for vas $\left(\mathrm{COO}^{-}\right)$and $1410 \mathrm{~cm}^{-1}$ for ${ }_{\text {ss }}\left(\mathrm{COO}^{-}\right)$thus confirming the zwitterion form 

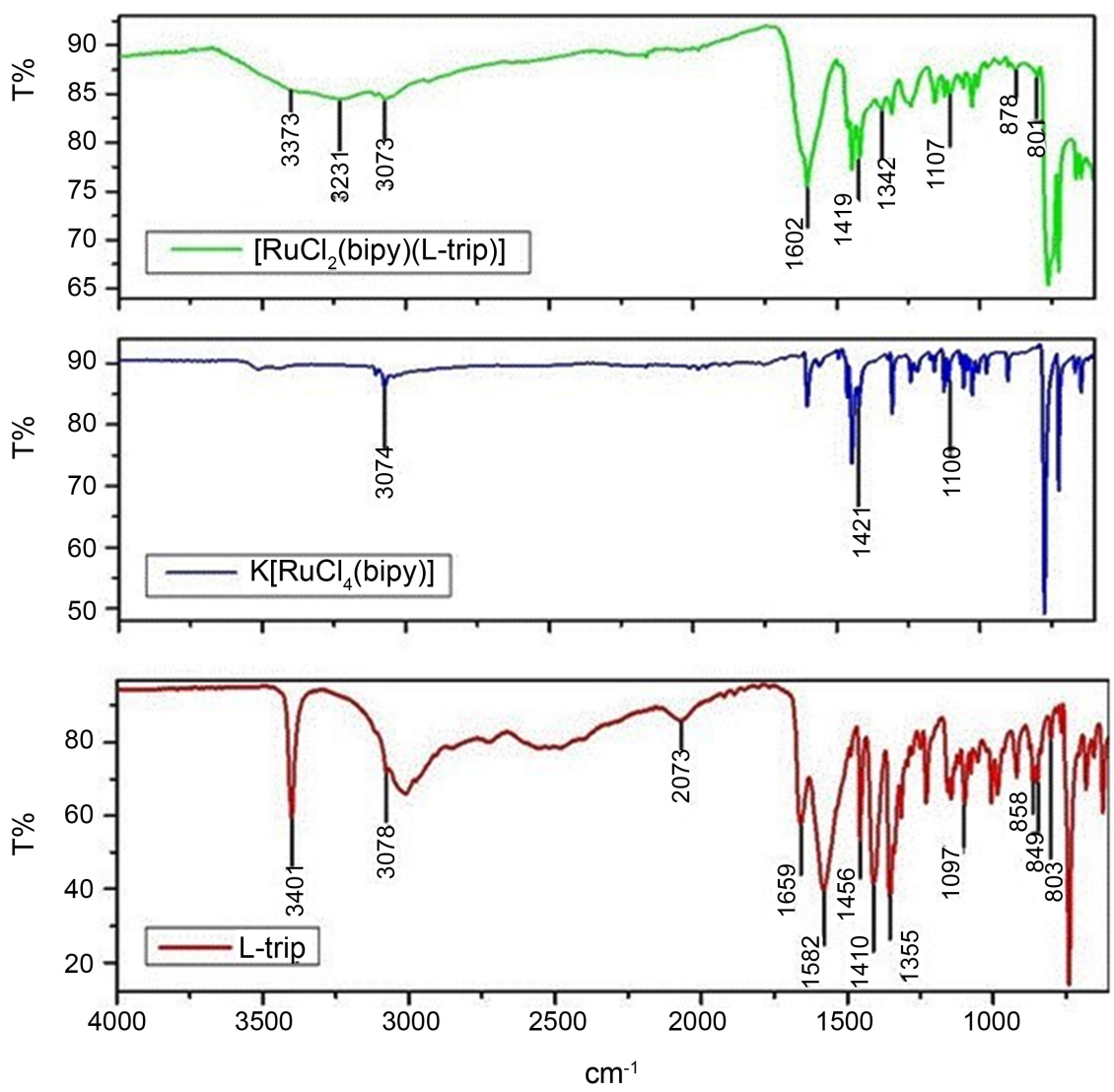

Figure 2. FTIRmed spectrum of the studied compounds.

for the free ligand. The disappearance of the band at $2073 \mathrm{~cm}^{-1}$, due to oscillations in group torsion $\left(\mathrm{NH}^{3+}\right)$, indicates that the L-trip molecule is no longer in zwitterion form and coordination with the metal ion may occur by group $\mathrm{N}$ $\left(\mathrm{NH}_{2}\right)$. The band at $1659 \mathrm{~cm}^{-1}$, referring to $\delta_{\delta}\left(\mathrm{NH}^{3+}\right)$, seems to have shifted to lower energies and was overlapped by the displacement of vas $\left(\mathrm{COO}^{-}\right)$from 1582 to $1602 \mathrm{~cm}^{-1}$. This shift to lower energies is yet another indication that the deprotonated L-trip species has coordinated with the metal. For the compound [Cu(L-trip $\left.)_{2}\right]$, a band referring to the group $\delta_{\delta}\left(\mathrm{NH}_{2}\right)$ is observed at $1626 \mathrm{~cm}^{-1}$ [28]. The Ru-n bond formation can be corroborated by the absence of the $1097 \mathrm{~cm}^{-1}$ band present in the free ligand spectrum for the aliphatic ${ }_{v}(\mathrm{CN})$. The absence of this band indicates that a displacement of the band occurred, overlapping with other bands initially observed in the starting compound in the region of 1108 $\mathrm{cm}^{-1}$. For the compound $\left.[\mathrm{Cu} \text { (L-trip) })_{2}\right]$ a shift from $1097 \mathrm{~cm}^{-1}$ to $1107 \mathrm{~cm}^{-1}$ is observed, indicating the Ru-N bond of the aliphatic amine [28]. Further evidence of $\mathrm{Ru}-\mathrm{N}$ bond formation could be obtained by analyzing ras $\left(\mathrm{NH}_{2}\right)$ and ${ }_{\text {is }}\left(\mathrm{NH}_{2}\right)$ bands. However, this analysis becomes unfeasible, since a wide band, characteristic of the presence of water, is observed in the region of 3373 to 3231 $\mathrm{cm}^{-1}$.

The data obtained with FTIR $_{\text {med }}$ corroborate those obtained in the TG-DTA analysis, thus confirming the presence of water in the compound. For $\mathrm{Mn}^{+2}$, 
$\mathrm{Ni}^{+2}, \mathrm{Cu}^{+2}$ and $\mathrm{Zn}^{+2}$ compounds with L-trip, these bands are present between 3344 and $3270 \mathrm{~cm}^{-1}$ [29]. It is noted that the presence of water in the compound masks the indole ${ }_{v}(\mathrm{NH})$ band which can be observed at $3401 \mathrm{~cm}^{-1}$ in the free ligand. The decrease in intensity followed by overlap indicates that indole participates in intramolecular interactions. Despite the presence of water, it is still possible to observe the ${ }_{v}(\mathrm{CH})$ at $3073 \mathrm{~cm}^{-1}$. According to the literature, the carboxylate ion is very versatile and can coordinate in many ways [30].

For single-coordinated coordination, two behaviors are foreseen involving vas $\left(\mathrm{COO}^{-}\right)$at $1582 \mathrm{~cm}^{-1}$ and ${ }_{\text {ss }}\left(\mathrm{COO}^{-}\right)$at $1410 \mathrm{~cm}^{-1}$. Due to the generation of an $\mathrm{M}-\mathrm{O}$ bond, where $\mathrm{M}$ is a transition metal, the symmetry in the carboxylate ion is broken and the expected higher energy displacement of vas $\left(\mathrm{COO}^{-}\right)$by $1582 \mathrm{~cm}^{-1}$ and a lower energy displacement of ${ }_{\text {is }}\left(\mathrm{COO}^{-}\right)$by $1410 \mathrm{~cm}^{-1}$ [28] [30]. These shifts increase the distance between the frequencies relative to ${ }_{v}\left(\mathrm{COO}^{-}\right)$compared to the free binder in the form of sodium or potassium salt [30]. In the spectrum of the new compound, it is possible to observe a shift of the vas $\left(\mathrm{COO}^{-}\right)$ band from $1582 \mathrm{~cm}^{-1}$ to $1602 \mathrm{~cm}^{-1}$. This displacement, for higher energies, corroborates the expected for vas $\left(\mathrm{COO}^{-}\right)$. However, it seems that ${ }_{\text {is }}\left(\mathrm{COO}^{-}\right)$at 1410 $\mathrm{cm}^{-1}$ had a slight displacement to the region of $1419 \mathrm{~cm}^{-1}$, overlapping with the band at $1421 \mathrm{~cm}^{-1}$, initially observed in the starting compound, diverging than expected [28] [30]. Despite the unexpected behavior of ${ }_{v}\left(\mathrm{COO}^{-}\right)$at $1410 \mathrm{~cm}^{-1}$, the carboxylate ion is unlikely to be chelated or bridged to the metal [30]. In addition to indicative of Ru-N bond formation, obtained in FTIR med $_{\text {analysis, qua- }}$ litative tests on silver nitrate test tube and absence of precipitate confirm the presence of two chlorine atoms in the coordination sphere. The presence of these two chlorine atoms in the coordinating sphere makes it impossible for any type of carboxylate ion to bind other than the monodentate form. Even though ${ }_{\text {is }}\left(\mathrm{COO}^{-}\right)$has not shifted to lower energies, it is possible to observe an increase in the distance between frequencies relative to ${ }_{v}\left(\mathrm{COO}^{-}\right)$compared to the free binder in salt form. For the new compound, synthesized in this paper, the distance between the frequencies referring to ${ }_{v}\left(\mathrm{COO}^{-}\right)$is $183 \mathrm{~cm}^{-1}$. This result coincides with that expected for a monodentate carboxylate ion coordination [30]. In addition to what has already been discussed, it is possible in the spectrum of the new compound to observe bands that were not originally present in the spectrum of the precursor compound. These bands refer to indole ${ }_{\nu}(\mathrm{CN})$ at 1342 $\mathrm{cm}^{-1}$ and ${ }_{\mathrm{p}}\left(\mathrm{CH}_{2}\right)$ at 878 and $801 \mathrm{~cm}^{-1}$. In the free ligand are observed, respectively, in $1355,858,849$, and $803 \mathrm{~cm}^{-1}$. It is possible to notice small displacements that may be related to intramolecular interactions. This type of interaction is observed for the compound. [ $\mathrm{Ru}$ (bipy) ${ }_{2}\left(\mathrm{~L}\right.$-trip) $\mathrm{ClO}_{4}[26]$.

Amino acids can coordinate with transition metals in two ways, monodentate or bidentate, with the most frequent bidentate form being [31] [32]. Analysis of the above spectra gives strong evidence of the formation of the $\mathrm{Ru}-\mathrm{O}$ and $\mathrm{Ru}-\mathrm{N}$ bond with lymphatic amine nitrogen. FTIR $_{\text {med }}$ analysis allows us to evaluate that the L-trip molecule coordinates in a bidentate manner to the metallic center. This type of coordination fits well with that described for ruthenium L-trip 
compounds, [26] [32] covers [28] [33], platinum [34] [35], palladium [35], among others.

Cytotoxic evaluation of ruthenium compounds. The acridine orange staining assay allowed the distinction between living and dead cells in each of the experimental groups, thus allowing to evaluate if the tested compounds presented toxicity to the PBMC and MCF-7 cells. The degeneration processes, as well as their probable mechanisms, will be evaluated in further tests.

The data obtained by analysis of variance (ANOVA) followed by the multiple comparisons test (Tukey) give us results with $95 \%$ reliability. Thus, it is possible to state that there are no significant differences in cell death between the PBMC/MCF-7 groups, showing us that the rate of dead cells was similar in both strains. (Figure 3):

By analyzing the graph it are possible to notice that there is no significant difference between the PBMC/PBMC $+\mathrm{K}\left[\mathrm{RuCl}_{4}(\right.$ bipy) $]$ and $\mathrm{PBMC} / \mathrm{PBMC}+$ $\left[\mathrm{RuCl}_{2}\right.$ (bipy)(L-trip)] groups, which shows us that, statistically, the tested stimuli have no toxic effects on the healthy cells used. However, when analyzing the MCF-7/MCF-7 + K[RuCl 4 (bipy) $]$ and MCF-7/MCF-7 + [ $\mathrm{RuCl}_{2}$ (bipy)(L-trip) $]$ groups, it is possible to observe an increase in cell death in both cases. These data demonstrate that both tested stimuli have toxic effects on the tumor cells of the MCF-7 type.

Very interesting data is obtained when comparing the $\mathrm{PBMC}+\mathrm{K}\left[\mathrm{RuCl}_{4}(\right.$ bipy $\left.)\right] /$ MCF-7 + $\mathrm{K}\left[\mathrm{RuCl}_{4}\right.$ (bipy) $]$ and PBMC $+\left[\mathrm{RuCl}_{2}\right.$ (bipy)(L-trip) $] / \mathrm{MCF}-7+\left[\mathrm{RuCl}_{2}\right.$ (bipy)(L-trip)] groups. When evaluating the graph, it is verified that there is no significant difference in the PBMC $+\left[\mathrm{RuCl}_{2}(\right.$ bipy $)(\mathrm{L}$-trip) $] / \mathrm{MCF}-7+\left[\mathrm{RuCl}_{2}(\right.$ bipy $)$ (L-trip)] group, but when evaluating the $\mathrm{PMC}+\mathrm{K}\left[\mathrm{RuCl}_{4}(\right.$ bipy) $] / \mathrm{MCF}-7+\mathrm{K}\left[\mathrm{RuCl}_{4}\right.$ (bipy)] group, there is a significant increase in cell death.

These latter comparisons suggest that the insertion of the L-trip molecule into the $\mathrm{K}\left[\mathrm{RuCl}_{4}\right.$ (bipy)] complex significantly increased compound selectivity by MCF-7 tumor cells. Increased selectivity by tumor cells is as expected for expected

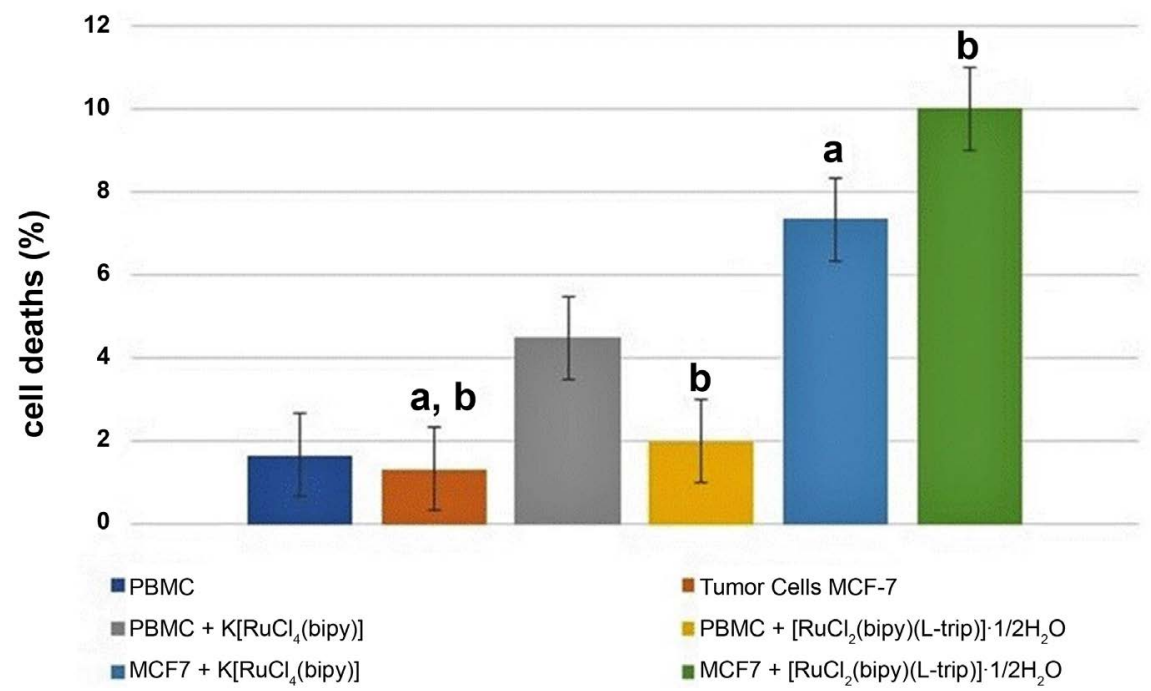

Figure 3. Comparison of cell deaths in \%. 
ruthenium-derived compounds [7] [8]. Some ruthenium-derived compounds show some selectivity for tumor cells as compared to PBMC cells. This is the case of the cis- $\left[\mathrm{RuCl}_{2}\left(\mathrm{NH}_{3}\right)_{4}\right] \mathrm{Cl}$ compound which has relevant toxicity for A-20, SK-Br-3, and S-180 strains, moderate in Jurkat cells and very low toxicity in PBMC cells when compared to strains. A-20, SK-Br-3, and S-180 [23].

\section{Conclusion}

From the precursor $\mathrm{K}\left[\mathrm{RuCl}_{4}(\right.$ bipy)] a simple and reproducible synthesis route for a new $\mathrm{Ru}^{+3}$ coordination compound with bipy and L-trip was generated in the present work. Due to the thermal instability of the new compound, it was not possible to develop a purification process for it. Spectroscopic characterization gives us strong indications of Ru-(L-trip) interaction. The displacement of the carboxylate ion band at higher energies in FTIR med $_{\text {and }}$ and the absence of aliphatic amine bands indicate bidentate coordination of the L-trip ligand to the ruthenium metal. With studies in thermoanalytical techniques, it is possible to suggest the minimum formula of the compound, $\left[\mathrm{RuCl}_{2}\right.$ (bipy)(L-trip) $] \cdot 1 / 2 \mathrm{H}_{2} \mathrm{O}$. The new compound was thermally unstable, qualitative test tube testing and heat synthesis synthesize thermal instability below $100^{\circ} \mathrm{C}$ with the release of an odor similar to that generated by L-trip burning. The evaluation of the antitumor potential of precursor $\mathrm{K}\left[\mathrm{RuCl}_{4}(\right.$ bipy) $]$ showed that it has considerable toxic effects on the MCF-7 cell line, but it did not show selectivity and not reached PBMC cells in the same proportion. Evaluation of the antitumor potential of $\left[\mathrm{RuCl}_{2}\right.$ (bipy)(L-trip) $] \cdot 1 / 2 \mathrm{H}_{2} \mathrm{O}$ showed selectivity for MCF-7 cells as compared to PBMC cells.

\section{Acknowledgements}

Federal University of Mato Grosso (UFMT), Materials Research Lab (LEMAt), FAPEMAT (227937/2015) and CAPES.

\section{Author Contributions}

Conceptualization, Wagner Santos; Data curation, Fabricio Moraes and Dario Fortaleza; Formal analysis, Fabricio Moraes; Funding acquisition, Wagner Santos; Investigation, Claudia Sousa; Methodology, Fabricio Moraes and Claudia Sousa; Project administration, Wagner Santos; Resources, Adenilda Honorio-França, Eduardo França and Wagner Santos; Software, Dario Fortaleza and Kelly Amorim; Supervision, Wagner Santos; Validation, Fabricio Moraes, Kelly Amorim and Daniel Costa; Visualization, Fabricio Moraes and Anderson Galvão; Writing original draft, Fabricio Moraes; Writing review \& editing, Wagner Santos.

\section{Funding}

This research received no external funding.

\section{Conflicts of Interest}

The authors declare no conflicts of interest and that the ruthenium complex 
$\left[\mathrm{RuCl}_{2}\right.$ (bipy)(L-trip)] $1 / 2 \mathrm{H}_{2} \mathrm{O}$ synthesized in this work is unpublished. We further declare that no other study involving MCF-7 tumor cells was carried out with compound $\mathrm{K}\left[\mathrm{RuCl}_{4}(\right.$ bipy)$]$.

\section{References}

[1] Rosenberg, B., Van Camp, L., Grimley, E.B. and Thomson, A.J. (1967) The Inhibition of Growth or Cell Division in Escherichia coli by Different Ionic Species of Platinum (IV) Complexes. Journal of Biological Chemistry, 242, 1347-1352.

[2] Rosenberg, B., Van Camp, L. and Krigas, T. (1965) Inhibition of Cell Division in Escherichia coli by Electrolysis Products from a Platinum Electrode. Nature, 205, 698-699. https://doi.org/10.1038/205698a0

[3] Rosenberg, B. and VanCamp, L. (1970) The Successful Regression of Large Solid Sarcoma 180 Tumors by Platinum Compounds. Cancer Research, 30, 1799-1802.

[4] de Almeida, S.M.V., de Alcantara, F.F., de Brito, C.G.X., de Souza, G.C.A., Lafayette, E.A., da Silva, V.B.R., Carvalho, M.S. and de Lima, M.C.A. (2015) Compostos coordenados híbridos de platina no tratamento do câncer. Revista de Ciências Farmacêuticas Básica e Aplicada, 35, 337-345.

[5] Rosenberg, B. (1985) Charles F. Kettring Prize. Fundamental Studies with Cisplatin. Cancer, 55, 2303-2316. https://doi.org/10.1002/1097-0142(19850515)55:10<2303::AID-CNCR2820551002> 3.0.CO;2-L

[6] Brabec, V. and Kasparkova, J. (2005) Modifications of DNA by Platinum Complexes: Relation to Resistance of Tumors to Platinum Antitumor Drugs. Drug Resistance Updates, 8, 131-146. https://doi.org/10.1016/j.drup.2005.04.006

[7] Allardyce, C.S. and Dyson, P.J. (2001) Ruthenium in Medicine: Current Clinical Uses and Future Prospects. Platinum Metals Review, 45, 62-69.

[8] Silva, P.P. and Guerra, W. (2012) Rutenio. Quimica Nova na Escola, 34, 99-100.

[9] Gallori, E., Vettori, C., Alessio, E., Vilchez, F.G., Vilaplana, R., Orioli, P., Casini, A. and Messori, L. (2000) DNA as a Possible Target for Antitumor Ruthenium (III) Complexes: A Spectroscopic and Molecular Biology Study of the Interactions of Two Representative Antineoplastic Ruthenium (III) Complexes with DNA. Archives of Biochemistry and Biophysics, 376, 156-162. https://doi.org/10.1006/abbi.1999.1654

[10] Clarke, M.J. (1989) Ruthenium and Other Non-Platinum Metal Complexes in Cancer Chemotherapy. Springer, New York.

[11] van Vliet, P.M., Toekimin, S.M.S., Haasnoot, J.G., Reedijk, J., Nováková, O., Vrána, O. and Brabec, V. (1995) mer-[Ru(terpy)Cl3] (terpy = 2,2':6',2”-terpyridine) Shows Biological Activity, Forms Interstrand Cross-Links in DNA and Binds Two Guanine Derivatives in a Trans Configuration. Inorganica Chimica Acta, 231, 57-64. https://doi.org/10.1016/0020-1693(94)04320-U

[12] Novakova, O., Kasparkova, J., Vrana, O., van Vliet, P.M., Reedijk, J. and Brabec, V. (1995) Correlation between Cytotoxicity and DNA Binding of Polypyridyl Ruthenium Complexes. Biochemistry, 34, 12369-12378. https://doi.org/10.1021/bi00038a034

[13] Sava, G., Zorzet, S., Giraldi, T., Mestroni, G. and Zassinovich, G. (1984) Antineoplastic Activity and Toxicity of an Organometallic Complex of Ruthenium (II) in Comparison with cis-PDD in Mice Bearing Solid Malignant Neoplasms. European Journal of Cancer and Clinical Oncology, 20, 841-847. 
https://doi.org/10.1016/0277-5379(84)90223-2

[14] Alessio, E. (2017) Thirty Years of the Drug Candidate NAMI-A and the Myths in the Field of Ruthenium Anticancer Compounds: A Personal Perspective. European Journal of Inorganic Chemistry, 2017, 1549-1560. https://doi.org/10.1002/ejic.201600986

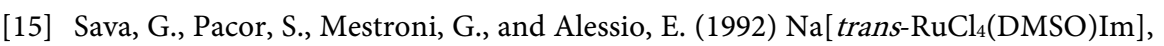
a Metal Complex of Ruthenium with Antimetastatic Properties. Clinical \& Experimental Metastasis, 10, 273-280. https://doi.org/10.1007/BF00133563

[16] Sava, G., Pacor, S., Mestroni, G. and Alessio, E. (1992) Effects of the Ru (III) Complexes $\left[\right.$ mer- $\left.\mathrm{RuCl}_{3}(\mathrm{DMSO}) 2 \mathrm{Im}\right]$ [degrees] and $\mathrm{Na}$ [trans- $\left.\mathrm{RuCl}_{4}(\mathrm{DMSO}) \mathrm{Im}\right]$ on Solid Mouse Tumors. Anti-Cancer Drugs, 3, 25-32. https://doi.org/10.1097/00001813-199202000-00005

[17] Bergamo, A. and Sava, G. (2015) Linking the Future of Anticancer Metal-Complexes to the Therapy of Tumour Metastases. Chemical Society Reviews, 44, 8818-8835. https://doi.org/10.1039/C5CS00134J

[18] Frasca, D.R., Gehrig, L.E. and Clarke, M.J. (2001) Cellular Effects of Transferrin Coordinated to $\left[\mathrm{Cl}\left(\mathrm{NH}_{3}\right)_{5} \mathrm{Ru}\right] \mathrm{Cl}_{2}$ and cis- $\left[\mathrm{Cl}_{2}\left(\mathrm{NH}_{3}\right)_{4} \mathrm{Ru}\right] \mathrm{Cl}$. Journal of Inorganic Biochemistry, 83, 139-149. https://doi.org/10.1016/S0162-0134(00)00180-X

[19] de Lima, A.P., Pereira, F.C., Vilanova-Costa, C.A.S.T., Soares, J.R., Pereira, L.C.G., Porto, H.K.P., Pavanin, L.A., dos Santos, W.B. and Silveira-Lacerda, E.P. (2012) Induction of Cell Cycle Arrest and Apoptosis by Ruthenium Complex cis-(dichloro) Tetramineruthenium (III) Chloride in Human Lung Carcinoma Cells A549. Biological Trace Element Research, 147, 8-15. https://doi.org/10.1007/s12011-011-9275-7

[20] Menezes, C.S.R., de Paula Costa, L.C.G., Ávila, V.M.R., Ferreira, M.J., Vieira, C.U., Pavanin, L.A., Homsi-Brandeburgo, M.I., Hamaguchi, A. and de Paula Silveira-Lacerda, E. (2007) Analysis in Vivo of Antitumor Activity, Cytotoxicity and Interaction between Plasmid DNA and the cis-Dichlorotetraammineruthenium (III) Chloride. Chemico-Biological Interactions, 167, 116-124. https://doi.org/10.1016/j.cbi.2007.02.003

[21] Pereira, F.C., Lima, A.P.d., Vilanova-Costa, C.A.S.T., Pires, W.C., Ribeiro, A.S.B.B., Pereira, L.C.G., Pavanin, L.A., dos Santos, W.B. and Silveira-Lacerda, E.P. (2014) Cytotoxic Effects of the Compound cis-Tetraammine(oxalato)ruthenium (III) Dithionate on K-562 Human Chronic Myelogenous Leukemia Cells. SpringerPlus, 3, Article No.: 301. https://doi.org/10.1186/2193-1801-3-301

[22] Silveira-Lacerda, E.P., de Lima, A.P., Pereira, F.C., Vilanova-Costa, C.A.S.T., Mello, F.M.S., Ribeiro, A.S.B.B., Benfica, P.L., Valadares, M.C., Pavanin, L.A. and dos Santos, W.B. (2010) The Compound cis-(Dichloro)tetrammineruthenium(III) Chloride Induces Caspase-Mediated Apoptosis in K562 Cells. Toxicology in Vitro, 24, 1562-1568. https://doi.org/10.1016/j.tiv.2010.06.015

[23] Silveira-Lacerda, E.P., Vilanova-Costa, C.A.S.T., Hamaguchi, A., Pavanin, L.A., Goulart, L.R., Homsi-Brandenburgo, M.I., dos Santos, W.B., Soares, A.M. and Nomizo, A. (2009) The Ruthenium Complex cis-(Dichloro)tetraammineruthenium (III) Chloride Presents Selective Cytotoxicity against Murine B Cell Lymphoma (A-20), Murine Ascitic Sarcoma 180 (S-180), Human Breast Adenocarcinoma (SK-BR-3), and Human T Cell Leukemia (Jurkat) Tumor Cell Lines. Biological Trace Element Research, 135, 98-111. https://doi.org/10.1007/s12011-009-8498-3

[24] Vilanova-Costa, C.A.S.T., Porto, H.K.P., Pereira, L.C.G., Carvalho, B.P., dos Santos, W.B. and Silveira-Lacerda, E.P. (2015) MDR1 and Cytochrome P450 Gene-Expression 
Profiles as Markers of Chemosensitivity in Human Chronic Myelogenous Leukemia Cells Treated with Cisplatin and Ru (III) Metallocomplexes. Biological Trace Element Research, 163, 39-47. https://doi.org/10.1007/s12011-014-0133-2

[25] James, B.R., and McMillan, R.S. (1975) A Convenient Synthesis of Potassium Hexachlororuthenate (III), and Potassium Tetrachloromono (Bipyridine) Ruthenate (III) and the Analogous Mono (Phenanthroline) Complex. Inorganic and Nuclear Chemistry Letters, 11, 837-839. https://doi.org/10.1016/0020-1650(75)80110-3

[26] Guo-Nan, C., Rong-Er, L., Zeng-Hong, X., Jian-Ping, D. and Zjang, L. (1998) Electrochemiluminescence of $\left[\mathrm{Ru}(\mathrm{bpy})_{2}(\mathrm{~L}-\mathrm{Trp})\right] \mathrm{ClO}_{4}$ Complex in Water Solution. Acta Chimica Sinica, 56, 433-438.

[27] Cao, X. and Fischer, G. (1999) Infrared Spectral, Structural, and Conformational Studies of Zwitterionic L-tryptophan. The Journal of Physical Chemistry A, 103, 9995-10003. https://doi.org/10.1021/jp992421c

[28] Wagner, C.C. and Baran, E.J. (2004) Spectroscopic and Magnetic Behaviour of the Copper (II) Complex of L-Tryptophan. Acta Farmaceutica Bonaerense, 23, 339-342.

[29] Mello, G.S., Carvalho, A.C.S., Cardoso, A.P. and Siqueira, A.B. (2016) Preparação, caracterização e avaliação do potencial antioxidante de compostos L-triptofano com Mn (II), Ni (II), Cu (II) e Zn (II). Brazilian Journal of Thermal Analysis, 5, 7-15. https://doi.org/10.18362/bjta.v5i1.2

[30] Deacon, G.B. and Phillips, R.J. (1980) Relationships between the Carbon-Oxygen Stretching Frequencies of Carboxylato Complexes and the Type of Carboxylate Coordination. Coordination Chemistry Reviews, 33, 227-250. https://doi.org/10.1016/S0010-8545(00)80455-5

[31] Nakamoto, K. (2009) Infrared and Raman Spectra of Inorganic and Coordination Compounds, Applications in Coordination, Organometallic, and Bioinorganic Chemistry. John Wiley \& Sons, Hoboken.

[32] Porto, H.K.P., Vilanova-Costa, C.A.S.T., dos Santos Mello, F.M., da Costa, W.L., de Lima, A.P., de Castro Pereira, F., Almeida, M.A.P., Graminha, A.E., Batista, A.A. and de Paula Silveira-Lacerda, E. (2015) Synthesis of a Ruthenium (II) Tryptophan-Associated Complex and Biological Evaluation against Ehrlich Murine Breast Carcinoma. Transition Metal Chemistry, 40, 1-10. https://doi.org/10.1007/s11243-014-9882-1

[33] Selvakumar, P.M., Suresh, E. and Subramanian, P. (2009) Single Stranded Helical Supramolecular Architecture with a Left Handed Helical Water Chain in Ternary Copper (II) Tryptophan/Diamine Complexes. Polyhedron, 28, 245-252. https://doi.org/10.1016/j.poly.2008.10.072

[34] Kumar, L., Kandasamy, N., Srivastava, T., Amonkar, A., Adwankar, M. and Chitnis, M. (1984) Synthesis and Spectroscopic Studies of Potential Anticancer [Platinum (II) (2, 2'-bipyridine)(amino acid) $] \mathrm{n}+(\mathrm{n}=1$ or 2) Complexes. Journal of Inorganic Biochemistry, 23, 1-11. https://doi.org/10.1016/0162-0134(84)85001-1

[35] Mital, R., Srivastava, T.S., Parekh, H.K. and Chitnis, M.P. (1991) Synthesis, Characterization, DNA Binding, and Cytotoxic Studies of Some Mixed-Ligand Palladium(II) and Platinum(II) Complexes of $\alpha$-Diimine and Amino Acids. Journal of Inorganrc Blochemrstry, 41, 93-103. https://doi.org/10.1016/0162-0134(91)80003-Z 